\title{
Can Strategies to Cope with Hazard Shocks be Explained by At-Risk Households' Socioeconomic Asset Profile? Evidence from Tropical Cyclone-Prone Coastal Bangladesh
}

\author{
Md. Nasif Ahsan'
}

Published online: 24 March 2017

(c) The Author(s) 2017. This article is an open access publication

\begin{abstract}
This article documents the results of an empirical investigation on the complex interplay between diverse coping mechanisms and the socioeconomic asset profiles of coastal households at risk. Focusing on household-level perceptions and responses to cyclone hazards, a case study was carried out in a poor area in Bangladesh that is prone to natural hazards. We developed and tested our own analytical models based on the asset approach. We conducted a face-to-face household survey in southwestern coastal Bangladesh, in the Koyra sub-district, in late 2009. We asked 360 households affected by the May 2009 tropical Cyclone Aila about their hazard perceptions, preparedness, coping practices, and socioeconomic assets. The results suggest that the majority of households at risk perceive an increasing trend of different climate hazards, with a distinct dominance of tropical cyclones, storm surges, and flash floods in the study area, which resulted in a yearly average economic damage of USD 144 for each household in the first year after Aila. However, such damage is significantly and inversely correlated with the number of adopted coping practices. Significant and systematic differences exist between upstream and downstream households in the study area with respect to hazard perception, hazard induced damages, asset accessibility, and adopted diversified coping practices. The empirical findings suggest that the degree of adoption of coping practices depends primarily on elements of socioeconomic asset profile and the duration of the consequences of cyclone hazards. Disaster preparedness training seems to
\end{abstract}

Md. Nasif Ahsan

nasif.ahsan@yahoo.com; nasif.ahsan@econ.ku.ac.bd

1 Economics Discipline, Khulna University, Khulna-9208, Bangladesh improve at-risk households' degree of information access and eventually leads them to adopt more coping practices to reduce adverse impacts of climate hazards. Area-specific practical modules on coping practices should be incorporated in curricula of disaster preparedness training to make people at risk more resilient to hazard shocks.

Keywords Climatic hazard risk - Coastal Bangladesh · Coping mechanism · Cyclone Aila

\section{Introduction}

Human population has been adapting to the cumulative adverse impacts of climate change over a long period of time. Over the last several decades intensity and frequency of extreme climatic events have substantially increased across the globe and jeopardized human lives and livelihoods (United Nations 2010; Michel-Kerjan and Kunreuther 2011). The latest Assessment Report (AR5) by the Intergovernmental Panel on Climate Change (IPCC) suggests that while the frequency of tropical cyclones globally is likely to either decrease or remain unchanged in the future, their intensity is likely to increase, with heavier precipitation and greater wind speeds, which would significantly exacerbate direct economic losses and result in the escalation of at-risk peoples' socioeconomic vulnerability (IPCC 2012a, 2014). Current and projected future scenarios call for optimal efforts to lessen the vulnerability of human populations to extreme climatic events. An important aspect of dealing with adverse effects and impacts of such events is to adopt suitable coping strategies. From this perspective, asset-dependent livelihood options of people at risk are greatly influenced by coping mechanisms while addressing risks from extreme climatic 
events, especially in rural areas of developing countries (Moser 2006; Heltberg et al. 2009). Therefore, it is necessary to investigate the diverse strategies that people at risk deploy while coping with shocks from extreme events and how they perceive and foresee the impacts of these catastrophes.

Poor and marginalized people in developing countries are more likely to depend heavily on natural resources (for example, agriculture, fishery) for their livelihoods (Helgeson et al. 2013). In coastal areas people at risk greatly depend on climate sensitive sectors, such as fishery, forestry, and tourism, for their livelihoods and very often need to adopt a number of strategies to cope with shocks inflicted by different climate hazards (Parvin et al. 2009). A handful of empirical studies have addressed three types of strategies: informal coping strategies, such as borrowing from peer networks, adjustment in household consumption, asset deposition or adjustment, resource extraction, labor supply adjustment, and temporary migration (Paul and Routray 2010, 2011; Kartiki 2011; Mallick and Vogt 2012; Mavhura et al. 2013; Vincent et al. 2013; Toufique and Islam 2014); formal strategies, such as market-oriented instruments (for example, private micro-insurance, microfinance, group loans, safety nets) (Balgah and Buchenrieder 2010; Akter et al. 2011; Parvin and Shaw 2013; Zheng and Byg 2014); and farm household strategies that focus on agricultural issues in different countries (Kelly and Adger 1999; Eriksen et al. 2005; Below et al. 2012). All these studies have largely focused on specific dimensions of coping strategies (that is, formal or informal; agricultural or nonagricultural) and lacked detailed accounts of diverse strategies and their connection to household asset profiles. ${ }^{1}$ Little knowledge is available on the linkages between households' diversified coping mechanisms and their socioeconomic asset profiles.

This study builds on a steadily increasing number of conceptual and empirical studies on risks triggered by extreme climatic events and assesses the local coping strategies for cyclone hazards in coastal Bangladesh, one of the poor and natural hazard-prone countries in the world. In a face-to-face household survey conducted in southwestern coastal Bangladesh in November/December 2009, 360 households, victims of tropical Cyclone Aila in May 2009, were interviewed about their coping practices with risks from different climate hazards. We also conducted six focus group discussions (FGDs) with local inhabitants to identify and assess socioeconomic features and existing coping practices in the coastal area. The study investigates

\footnotetext{
${ }^{1}$ An asset profile reflects the possession of assets, including the degree of access to different productive household assets that are directly and/or indirectly related to income generation and welfare (Wisner et al. 2004).
}

and provides empirical evidence on mutual links between diverse coping mechanisms (that is, coping practices) and socioeconomic asset profiles of the coastal households at risk and aims to answer three specific research questions: (1) What are the distributional patterns of the most common coping practices in the study area and what are the reasons for these patterns (if any)? (2) What are the major elements of the socioeconomic asset profiles of the households at risk? and (3) To what extent do asset profiles affect the coping practices of households? The term "coping practices" is used interchangeably with coping mechanisms, coping strategies, and coping options.

\section{Conceptual Background and Framework}

With a view to lessening risks from climate hazards, adaptation is increasingly considered a core activity over mitigation (Füssel 2007). For human systems, the IPCC defines adaptation to climate change as "an adjustment process towards actual or potential climate shock effects to minimize adverse or exploit beneficial opportunities" (IPCC 2012b, p. 556). The thematic cross-disciplinary division with regard to coping and adaptation emerges when their innate characteristics are taken into consideration (Smit and Wandel 2006). In this backdrop, the definitional paradigm of the coping response becomes complicated when societal components and risk perception are introduced in the said paradigm (Schmidtlein et al. 2008; Lo 2013). Different knowledge fields have come up with divergent definitions of coping, but it is commonly understood as a temporary survival strategy that is adopted in a given context of responding to climate variability and extremes (Dercon 2002; Pelling 2011). Conversely, the notion of adaptation revolves around quasi-permanent or long-term adjustments in a social-ecological system, invoking some basic rearrangement in the system, including its institutional arrangement and the rules of the game (Kelly and Adger 2000; Smit and Pilifosova 2003). Institutional arrangements, in general, refer to the governance structures that provide bargaining power to the parties involved in transactions, ensure the rights mentioned in contracts, and establish rights of control on income prospects (Slangen et al. 2008). Adaptation is reflected through the capacity of the system, implying the degree of access to or possession with necessary assets (known as asset profile or asset entitlement) within a given institutional framework (Kelly and Adger 2000; Smit et al. 2000). As pointed out by Smit and Wandel (2006), a system's first defense is governed by its intrinsic characteristic known as "coping capacity," which consists of capacities of absorbing, accommodating, responding, and recovering from adverse effects of climate shocks. Adaptation occurs 
when an exogenous shock exceeds the critical threshold level of the coping capacity of a system. Coping occurs first, followed by adaptation and the application of new and relatively diverse strategies (Dercon 2002).

\subsection{The Asset-Based Approach}

The asset-based approach provides a framework for revealing mutual links between risks, exposure, and sensitivity of humans, and risk management (that is, coping/ adaptation).

Considering the entitlement approach by Sen (1981) and other relevant sources (Kelly and Adger 2000; Koli 2013), asset-based livelihood approaches are based on the idea that a household's well-being is multifaceted and positively linked to the degree of access to assets and livelihood options (Moser 2006). Household assets are categorized into three types: productive (for example, human, natural, physical, and financial resources), sociopolitical (for example, the degree of access to the societal decisionmaking process), and locational (for example, proximity to a business center) (Siegel 2005) (Fig. 1). Socioeconomic asset profiles of households constitute their decision on the use and/or rearrangement of assets, known as livelihood strategy, which is influenced by both internal and external institutional arrangements along with risk exposure (Wisner et al. 2004). The sustainability of households' livelihoods depends on the interplay between risks, socioeconomic asset profiles, and institutional arrangements in terms of income prospects. A demarcation can be drawn between ex-ante risk management and ex-post coping strategies; the first includes measures of risk reduction and compensation for negative shocks (for example, decrease in income) in pre-hazard periods, the second implies strategies to recover from shocks in posthazard periods. Asymmetric institutional arrangements such as social differentiation, exclusion, and marginalization are likely to exacerbate the immediate effects and impacts of hazard shocks on households at risk in society (Gallopín 2006; Wisner et al. 2012).

In the context of extreme climatic events, the assetbased approach provides a comprehensive framework to examine peoples' responses to idiosyncratic (for example, death or injury of a household member) and covariate (for example, cyclone and flood) shocks through coping strategies. Households at risk usually deploy their available assets to cope with shocks when assured that benefits will result at the expense of the assets. Following a shock, these households are likely to use fewer coping options other than exhausting their assets (Paul and Routray 2011).
Fig. 1 The asset-based approach to assessing strategies to cope with hazard shocks. Source: Adapted from Siegel (2005)

\begin{tabular}{|c|c|c|c|c|}
\hline \multicolumn{3}{|c|}{ Household Assets } & \multicolumn{2}{|c|}{ Institutional Context } \\
\hline Productive & $\begin{array}{r}\text { Social and } \\
\text { Political }\end{array}$ & Locational & Community and Local & $\begin{array}{l}\text { National and } \\
\text { Global }\end{array}$ \\
\hline $\begin{array}{l}\text { - Human } \\
\text { - Natural } \\
\text { - Financial }\end{array}$ & $\begin{array}{l}\text { - Socio- } \\
\text { political } \\
\text { networks }\end{array}$ & $\begin{array}{l}\text { - Agro- } \\
\text { ecological } \\
\text { - Proximity to } \\
\text { markets } \\
\text { - Access to } \\
\text { infrastructure }\end{array}$ & $\begin{array}{l}\text { - Community and local } \\
\text { institutions } \\
\text { - Norms, values, and } \\
\text { customs } \\
\text { - Services (for example, } \\
\text { medical, education, } \\
\text { utilities, and sanitation) } \\
\text { - Exclusion } \\
\text { - Marginalization }\end{array}$ & $\begin{array}{l}\text { - Institutional } \\
\text { arrangements } \\
\text { - Rules of the } \\
\text { game } \\
\text { - Governance } \\
\text { - Regulatory } \\
\text { policy } \\
\text { framework } \\
\text { - Property rights }\end{array}$ \\
\hline \multicolumn{5}{|c|}{1} \\
\hline \multicolumn{5}{|c|}{ Household-level risk management activities to smoothen livelihood } \\
\hline \multicolumn{3}{|c|}{$\begin{array}{l}\text { - On-farm activities } \\
\text { - Migration } \\
\text { - Activities to strengthen income- } \\
\quad \text { generating sources }\end{array}$} & \multicolumn{2}{|c|}{$\begin{array}{l}\text { activities (both agricultural and nonagricultural) } \\
\text { es } \\
\text { twork }\end{array}$} \\
\hline \multicolumn{3}{|c|}{$\mathbf{1}$} & \multicolumn{2}{|l|}{ 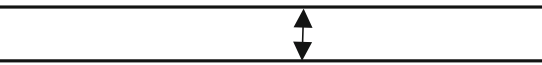 } \\
\hline \multicolumn{5}{|c|}{ Well-being oriented outcomes for household } \\
\hline \multicolumn{3}{|c|}{$\begin{array}{l}\text { - Consumption smoothing and savings } \\
\text { - Health status } \\
\text { - Social network and sense of togetherness } \\
\text { - Sense of social security }\end{array}$} & \multicolumn{2}{|c|}{$\begin{array}{l}\text { - Food security and nutritional status } \\
\text { - Empowerment and decision making } \\
\text { - Environmental quality } \\
\text { - Rational expectation }\end{array}$} \\
\hline
\end{tabular}


Households at risk are often inclined to use their readily accessible liquid assets as a short-term coping strategy during shocks, although this strategy may result in an assetbased poverty trap (Barrett et al. 2001; Dercon 2002). Paying attention to such poverty traps, along with the trade-offs between short-term coping and long-term adaptation strategies, is pivotal in terms of sustainable livelihood. This is especially true when addressing impacts from climatic hazards (Yamin et al. 2005a, b; Paul and Routray 2010; Wamsler and Brink 2014) and the harsh features of these hazards, such as speed of onset, severity, and duration that may result in indirect risks such as a sudden rise in food prices due to diminished agricultural production in response to climate extremes.

\section{Methodology}

In this section, we present the method of this article focusing on spatial features of our study area, adopted techniques of data collection, and analysis.

\subsection{Study Area}

We selected Koyra upazila (sub-district) in Khulna district of Bangladesh for the case study (Fig. 2). Koyra upazila is located in the southwestern part of Khulna district, covers an area of about $1800 \mathrm{~km}^{2}$, and is surrounded by the Sundarbans, the largest mangrove forest in the world and a UNESCO World Heritage Site (Banglapedia 2006).

The administrative structure of Koyra consists of seven union parishads (lowest tier of local government in Bangladesh), 71 mouzas (village-clusters), and 133 villages (BBS 2011). Geomorphologically, the upazila is about two meters above sea level in its northern part and about $1 \mathrm{~m}$ in its southern part. Koyra is made up of flat land, with a natural ground slope to the southeast and south along the Sundarbans and near the Bay of Bengal (Takagi et al. 2005). Biophysically it is characterized by an immature deltaic slope with numerous biotic and abiotic factors and a substantial portion of land that is hardly above sea level (PDO-ICZMP 2003; Banglapedia 2006; BBS 2011). As per the latest population census of 2011, with a population of 194,000 , Koyra has a population density of 109 people per $\mathrm{km}^{2}$, and the majority of the population manage livelihoods from different climate-sensitive sources such as cropping, fishing, and collecting forest resources (BBS 2013).

River Koyra is the main river in Koyra upazila. The other rivers such as Shibsha, Kobadak (also known as Kopataksha), Poshur, and Shakbaria have significant influence on both surface and groundwater quality due to their natural tidal patterns (PDO-ICZMP 2003). This region frequently experiences hydrometeorological hazards like tropical cyclones, tidal surges, flash floods, heavy precipitation, riverbank erosion, salinity intrusion and water-logging. Tropical cyclones Sidr and Aila devastated the region in 2007 and 2009, causing substantial economic and noneconomic damage.

\subsection{Data Collection and Analysis}

To realize the study objective, we collected primary data. In the first stage, the qualitative approaches of Rapid Rural Appraisal (RRA) proposed by Chambers (1994) were applied in the form of focus group discussions to gain insight into the types of common coping practices and the major socioeconomic asset patterns of the households in the study area. In November/December 2009, six focus group discussions were carried out in six union parishads of Koyra-Amadi, Bagali, Maharajpur, Koyra, Uttar Bedkashi, and Dakshin Bedkashi (Fig. 1). Participants from various groups of society-farmers, laborers, self-employed, local elites, ${ }^{2}$ officials from governmental organizations and NGOs-were invited. At least $90 \%$ of the discussion participants had to be Cyclone Aila victims, where the discussants (farmers, laborers, and self-employed) were from low income group. A panel consisted of five members-one from the local government, one representative of local NGOs, one from Khulna University (the local public university), one from the regional United Nations Development Programme (UNDP) office, and the author-facilitated the discussions. In all the focus group discussions, the participants from local NGOs were female who broadly were representatives of local women and provided an overall idea of the status of women in the study area. The six informal focus group discussions revealed the practices the coastal households adopted to cope with climate hazard risks in the 5 years before 2009 and an overall idea on their socioeconomic asset profiles. For the FGDs, the number of participants was 12-15 apart from the five facilitators. Activities in a FGD (for example, questions, answers, observations, and comments) took nearly one and half hour to be completed. The invitation for participating in FGDs was disseminated by the local experts and the discussants came to participate willingly even though no incentive such as sitting allowance and snacks was offered to them.

Subsequently, a quantitative survey at the household level was conducted to collect data on specific household coping practices and household socioeconomic assets. Twenty senior undergraduate students from Khulna University and three local experts were trained intensively

\footnotetext{
${ }^{2}$ Local elites include community leaders (for example, teachers, heads of local mosque committees) and people with political power (for example, village heads, political leaders).
} 


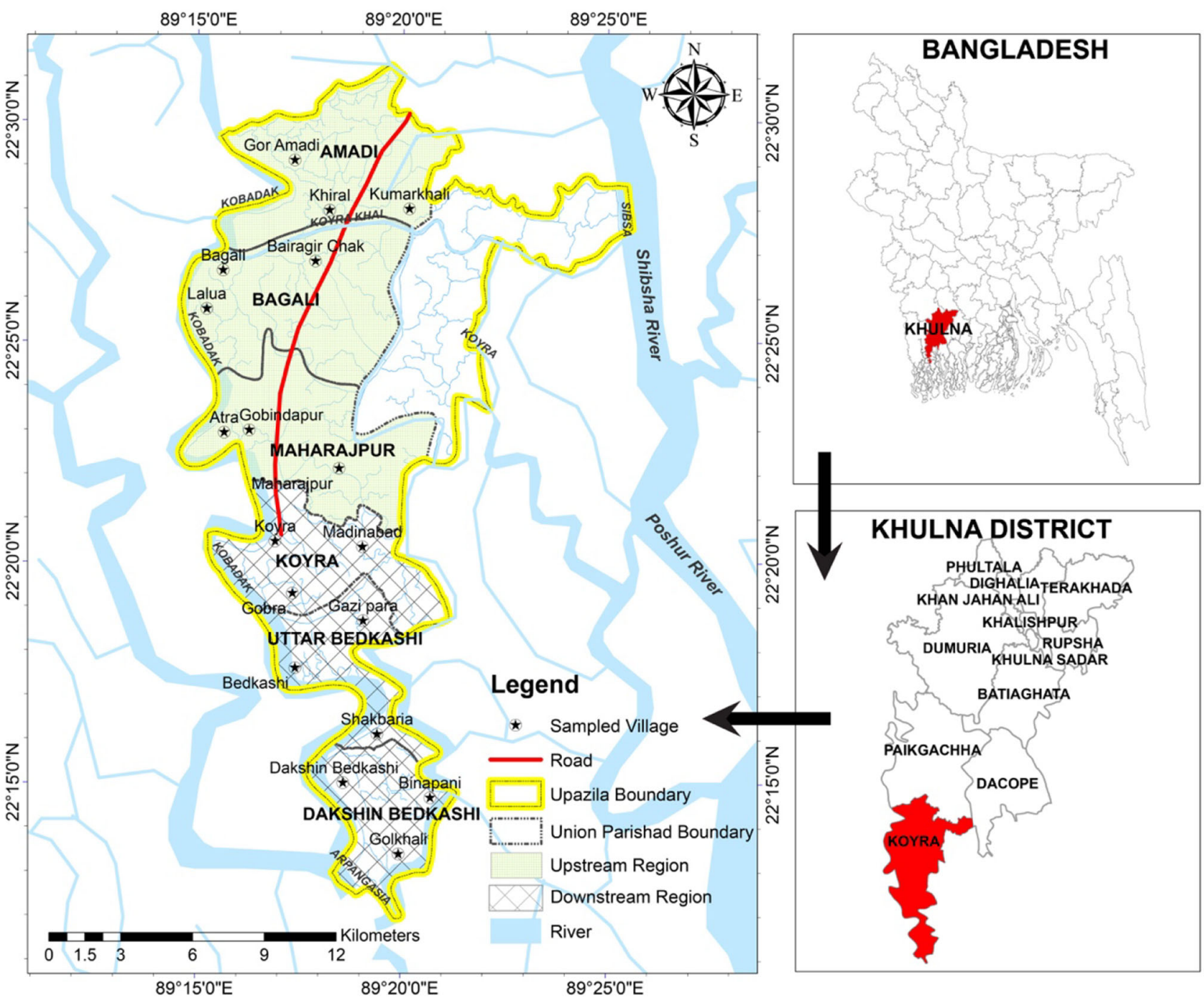

Fig. 2 Location of Koyra upazila in Bangladesh and the upstream and downstream villages sampled in November/December 2009 [prepared with data provided by the GIS unit of the Local
Government and Engineering Department (LGED) of the Government of the People's Republic of Bangladesh (LGED 2010)]

prepared following an iterative process. The initial draft was structured after the six focus group discussions and relevant discussions with experts-government officials, NGO workers, priests (Muslim Imams and Hindu Purohits), teachers from schools and colleges, and so on. The questionnaire was finalized after two rounds of pilot survey conducted by the author with two local experts in the study area. The final version of the questionnaire contained 32 main questions in one general section and two specific sections. The general section (ten main questions) focused on basic socioeconomic and sociodemographic household information. The two specific sections (22 main questions) focused on household coping mechanisms and climate hazard risk perceptions by using recall-type questions. Each survey interview took about half an hour to complete. 
We purposively divided Koyra upazila into two regions, upstream and downstream, where three union parishads were selected from each region (from the upstream region: Amadi, Bagali, and Maharajpur; from the downstream region: Koyra, Uttar Bedkashi, and Dakshin Bedkashi) (Fig. 2). Koyra upazila was divided into two study sections because the union parishads in the downstream region were inundated more substantially than those in the upstream region after Cyclone Aila (and during this survey in late 2009) due to embankment breaches in local rivers. We then randomly selected three villages from each union parishad, and from each village we randomly chose 20 households. The total sample consisted of 360 households from 18 villages in six union parishads (Fig. 2), 180 households in each region.

The data analysis was divided into two phases. First, the mutual links between hazard damages and coping mechanisms were assessed by applying linear correlation, parametric, and nonparametric testing tools. Secondly, we investigated whether the relationships between the coping mechanisms and different socioeconomic asset profiles of households would vary by using a deterministic model as shown in Eq. (1).

$C P_{i}=\alpha+\beta X_{i j}+\delta Y_{i j}+\varepsilon$

We used the same model (Eq. 1) for the downstream and upstream regions separately, and for Koyra as a whole (the two regions together). We consider $C P_{i}$ as an indicator of the sum of unique coping practices adopted by the sample households in the 5 years prior to the study. Coping practices here refers to both ex-ante risk management activities and ex-post coping options carried out by the sampled households for not more than 7 months a year. It was learned from the FGDs that people in the study area could continue a particular practice for a period of 5-7 months, and that was why coping option in this study is considered lasting for maximum 7 months. $X_{i j}$ and $Y_{i j}$ are variable sets indicating socioeconomic assets and time-invariant characteristics (for example, gender and safety-net membership) of households (Table 1), and $\varepsilon$ is treated as idiosyncratic error. We considered the timeinvariant household characteristics in order to control for heterogeneity biases. We adopted the above general form of deterministic model (Eq. 1) to investigate the empirical relationship between coping mechanisms and asset profiles, where subscript $i$ refers to households and $j$ indicates elements of asset profile or specific characteristics of concerned households, $\alpha$ denotes a constant, $\beta$ and $\delta$ are coefficients to be estimated. In line with the definitional paradigm suggested by Siegel (2005), this study considered literacy level, social capital, weather perception, resources index, information source, safety-net membership, and preparedness training participation as elements of the socioeconomic asset profile for the sampled households.

A statistical software package known as Stata (version 13) was used to obtain different test statistic (z-test, Chisquared test, correlation) results along with regression outputs of the deterministic model in Eq. (1).

\section{Results}

In this section, we first focus on the nexus between coping practices and hazard damage based on the characteristics of the sampled households (Table 2). Then we consider whether coping practices are affected by different elements of household asset profile (as specified in Table 1) by estimating Ordinary Least Square (OLS) regression models.

\subsection{General Characteristics of the Sampled Respondents}

The majority of the respondent household heads in both regions were male $(82 \%)$, and $18 \%$ of the respondent household heads were female (divorcee $8 \%$, widow $6 \%$, wife with a disabled husband $4 \%$ ). In this study, the household head was defined as the main income-earning member of the household. Most of the respondents (92\%) were born and brought up in Koyra. The average age of the interviewed household heads in both regions was around 40 years. More than $72 \%$ respondents' religion was Islam. Average household size was more than 4.5 persons in both regions, which is higher than that of 2011 population census (4.48 persons) for rural Bangladesh (BBS 2013). It is noteworthy that more than $71 \%$ of respondents in both regions depended on natural resources for their livelihood.

Despite a number of above-mentioned similarities between the upstream and downstream regions of Koyra, differences on some key issues also emerge as shown by Table 2. For example, the upstream region possessed higher female-male ratio, literacy level, respondents' living duration within same community, per capita consumption expenditure, land ownership, weather perception, disaster preparedness participation, and access to electricity, sanitary latrine, and clean drinking water than those of the downstream area. Conversely, the downstream region households had higher dependency ratio, proportion of people living below poverty threshold, ${ }^{3}$ households living

\footnotetext{
3 The poverty threshold was calculated in 2005 (and adjusted for 2008-2009) by applying the Cost of Basic Need (CBN) consumption as a poverty threshold value, which was USD 202/capita/year in 2008-2009 (BBS 2005, 2011, 2013). The CBN consumption consists of both food and non-food items required for maintaining the minimum living standard.
} 
Table 1 Variables hypothesized to influence households' coping practices in the face of hazard shocks in Koyra sub-district, Bangladesh

\begin{tabular}{lll}
\hline Variable & Measurement & $\begin{array}{l}\text { Expected } \text { Adapted source(s) }^{\mathrm{a}} \\
\text { relationship with } \\
\text { coping practices }\end{array}$ \\
\hline
\end{tabular}

Coping practice Sum of unique coping options (for example, sale of livestock) carried out at a stretch by the household for no more than 7 months a year in the previous 5 years

\begin{tabular}{|c|c|c|c|}
\hline Household size & Number of members in the household & Positive & Yohe and Tol (2002) \\
\hline Gender & $\begin{array}{l}\text { Household is male headed (binary variable): } 1=\text { male, } \\
0=\text { otherwise }\end{array}$ & Positive & Cutter et al. (2008) \\
\hline Age & Age of the household head (years) & Positive & Cutter et al. (2008) \\
\hline Female-male ratio & Ratio between male and female members in the household & Negative & Below et al. (2012) \\
\hline Dependency ratio & $\begin{array}{l}\text { Ratio of household members aged } 10 \text { years or younger and } 64 \text { years } \\
\text { or older to number of household members between } 11 \text { and } 63 \text { years } \\
\text { old }\end{array}$ & Negative & Below et al. (2012) \\
\hline Literacy level & Number of school years completed by the household head & Positive & $\begin{array}{l}\text { Démurger and Fournier } \\
\text { (2011) }\end{array}$ \\
\hline Social capital & Duration of staying in the current region (in years) & Positive & Ahsan and Warner (2014) \\
\hline $\begin{array}{l}\text { Per capita } \\
\quad \text { consumption } \\
\text { expenditure }\end{array}$ & $\begin{array}{l}\text { Annual per capita consumption for basic needs in USD in household } \\
\text { (proxy for poverty) }\end{array}$ & Positive & Ahsan and Warner (2014) \\
\hline $\begin{array}{l}\text { Perception of } \\
\text { weather-related } \\
\text { anomalies }\end{array}$ & $\begin{array}{l}\text { Number of weather parameter changes (such as temperature, hazard } \\
\text { frequency, and so on) perceived by the household in the two } \\
\text { decades prior to year } 2009^{\mathrm{b}}\end{array}$ & Positive & $\begin{array}{l}\text { Below et al. (2012); } \\
\text { Forgette and Van } \\
\text { Boening (2009) }\end{array}$ \\
\hline Resource index & $\begin{array}{l}\text { Index value for given resources of the household (proxy of wealth } \\
\text { indicator) }\end{array}$ & Positive & Adger and Kelly (1999) \\
\hline $\begin{array}{l}\text { Information } \\
\text { sources }\end{array}$ & $\begin{array}{l}\text { Number of information source(s) (such as television, radio, local } \\
\text { volunteer, mobile telephone, and so on) used by the household } \\
\text { since November } 2007 \text { for the purpose of collecting weather-related } \\
\text { information and forecasts }\end{array}$ & Positive & Saroar and Routray (2011) \\
\hline $\begin{array}{l}\text { Safety-net } \\
\text { membership }\end{array}$ & $\begin{array}{l}\text { Affiliation of the household with either a government or } \\
\text { nongovernment operated safety-net program (binary variable): } \\
\text { yes }=1 \text {, otherwise }=0\end{array}$ & Positive & Heltberg et al. (2009) \\
\hline $\begin{array}{l}\text { Preparedness } \\
\text { training } \\
\text { participation }\end{array}$ & $\begin{array}{l}\text { Household attended disaster preparedness training before cyclone } \\
\text { Aila (binary variable): yes }=1 \text {, otherwise }=0\end{array}$ & Positive & $\begin{array}{l}\text { Forgette and Van Boening } \\
\text { (2009) }\end{array}$ \\
\hline
\end{tabular}

${ }^{a}$ Main ideas of variables are adapted from these sources and later customized in line with the current study

b $P C_{j}=\sum_{i=1}^{m} W I_{i j}$, where $P C_{\mathrm{j}}=$ number of perceived changes by $j$ th household, $W I_{i=1} \ldots m=$ number of changes in weather parameters

${ }^{\mathrm{c}} R I_{j}=\frac{x_{i}-x_{\min }}{x_{\max }-x_{\min }}$, where $R I$ denotes resource index, with $x_{i}=$ number of resources (for example, land) possessed by household $j, x_{\max }=$ highest number of resources possessed in the sampled village, and $x_{\min }=$ lowest number of resources possessed in the sampled village

${ }^{\mathrm{d}} I S_{j}=\sum_{i=1}^{m} S_{i j}$, where $I S_{j}=$ number of sources accessed by $j$ th household, $S_{i=1} \ldots m=$ source accessed by $j$ th household for weather information

in weak settlements, hazard induced economic damage, and killed/injured household members than their counterpart region's households. These socioeconomic and demographic issues between the upstream and downstream regions differed significantly and systematically. ${ }^{4}$

\footnotetext{
$\overline{4}$ This implies the power of repetitive-measures design. In this case, the whole sample was divided into two groups (upstream and downstream) where "systematically" refers to effect size (that is, power) of the repetitive-measure, which is demonstrated by PointBiserial (r). For a more detailed explanation, see Field (2005).
}

The contrasts between these two regions on different socioeconomic and sociodemographic issues suggest that the downstream households are in a more disadvantaged position than those in the upstream region. For example, the number of poor people, as per poverty threshold definition of this study, living in the downstream region had been significantly higher than that in upstream. They could spend just over USD 100 per member of a household in a year for basic needs. This reflects their vulnerable living condition, which is validated by the findings on their weak 
Table 2 Major socioeconomic and demographic characteristics of sample households $(n=360)$ in Koyra, Bangladesh (November/December 2009)

\begin{tabular}{|c|c|c|c|}
\hline Characteristics & $\begin{array}{l}\text { Downstream }^{\mathrm{a}} \\
(n=180)\end{array}$ & $\begin{array}{l}\text { Upstream }^{\mathrm{a}} \\
(n=180)\end{array}$ & $\begin{array}{l}\text { Test statistic } \\
(p \text { value }) \\
(\text { effect size) }\end{array}$ \\
\hline Household size & $\begin{array}{l}4.54 \\
( \pm 1.53)\end{array}$ & $\begin{array}{l}5.38 \\
( \pm 1.82)\end{array}$ & $\begin{array}{l}4.77^{\mathrm{b}}(p<0.000) \\
{\left[0.18^{\mathrm{c}}\right]}\end{array}$ \\
\hline Households with male heads $(\%)$ & 76.67 & 87.22 & $\begin{array}{l}6.78^{\mathrm{d}}(p<0.000) \\
{\left[0.26^{\mathrm{c}}\right]}\end{array}$ \\
\hline Female-male ratio & $\begin{array}{l}0.87 \\
( \pm 0.66)\end{array}$ & $\begin{array}{l}1.08 \\
( \pm 0.69)\end{array}$ & $\begin{array}{l}2.89^{\mathrm{b}}(p<0.004) \\
{\left[0.15^{\mathrm{c}}\right]}\end{array}$ \\
\hline Dependency ratio & $\begin{array}{l}0.501 \\
( \pm 0.21)\end{array}$ & $\begin{array}{l}0.336 \\
( \pm 0.16)\end{array}$ & $\begin{array}{l}8.74^{\mathrm{b}}(p<0.000) \\
{\left[0.41^{\mathrm{c}}\right]}\end{array}$ \\
\hline Literacy level of household heads (school years) & $\begin{array}{l}3.61 \\
( \pm 2.43)\end{array}$ & $\begin{array}{l}5.28 \\
( \pm 3.49)\end{array}$ & $\begin{array}{l}5.27^{\mathrm{b}}(p<0.000) \\
{\left[0.25^{\mathrm{c}}\right]}\end{array}$ \\
\hline Living duration in the same community (years) & $\begin{array}{l}36.81 \\
( \pm 15.76)\end{array}$ & $\begin{array}{l}40.36 \\
( \pm 13.56)\end{array}$ & $\begin{array}{l}2.29^{\mathrm{b}}(p<0.023) \\
{\left[0.12^{\mathrm{c}}\right]}\end{array}$ \\
\hline Per capita consumption expenditure/year (USD) & $\begin{array}{l}106.55 \\
( \pm 68.75)\end{array}$ & $\begin{array}{l}183.48 \\
( \pm 92.57)\end{array}$ & $\begin{array}{l}8.95^{\mathrm{b}}(p<0.000) \\
{\left[0.43^{\mathrm{c}}\right]}\end{array}$ \\
\hline Households living below the poverty threshold $(\%)$ & 82.22 & 71.78 & $\begin{array}{l}23.57^{\mathrm{d}}(p<0.000) \\
{\left[0.26^{\mathrm{c}}\right]}\end{array}$ \\
\hline Dependent on natural sources for livelihood (\%) & 79.66 & 71.10 & $\begin{array}{l}5.29^{\mathrm{d}}(p<0.001) \\
{\left[0.31^{\mathrm{c}}\right]}\end{array}$ \\
\hline $\begin{array}{l}\text { Households living in weak houses (mud, straw, wood, and other light } \\
\text { materials) }(\%)\end{array}$ & 84.78 & 76.0 & $\begin{array}{l}10.86^{\mathrm{d}}(p<0.001) \\
{\left[0.17^{\mathrm{c}}\right]}\end{array}$ \\
\hline Land ownership (\%) & 37.78 & 61.11 & $\begin{array}{l}33.0^{\mathrm{d}}(p<0.000) \\
{\left[0.29^{\mathrm{c}}\right]}\end{array}$ \\
\hline Electricity $(\%)$ & 8.33 & 28.89 & $\begin{array}{l}25.11^{\mathrm{d}}(p<0.000) \\
{\left[0.26^{\mathrm{c}}\right]}\end{array}$ \\
\hline Sanitary latrine $(\%)$ & 48.33 & 70.0 & $\begin{array}{l}17.49^{\mathrm{d}}(p<0.000) \\
{\left[0.22^{\mathrm{c}}\right]}\end{array}$ \\
\hline Access to clean water $(\%)$ & 17.19 & 33.21 & $\begin{array}{l}9.08^{\mathrm{d}}(p<0.001) \\
{\left[0.26^{\mathrm{c}}\right]}\end{array}$ \\
\hline $\begin{array}{l}\text { Perception of weather anomalies (number of weather indicator changes } \\
\text { detected) }\end{array}$ & $\begin{array}{l}4.49 \\
( \pm 1.67)\end{array}$ & $\begin{array}{l}6.0 \\
( \pm 1.28)\end{array}$ & $\begin{array}{l}9.56^{\mathrm{b}}(p<0.000) \\
{\left[0.45^{\mathrm{c}}\right]}\end{array}$ \\
\hline Information source accessed by households (number) & $\begin{array}{l}2.05 \\
( \pm 1.42)\end{array}$ & $\begin{array}{l}3.74 \\
( \pm 1.11)\end{array}$ & $\begin{array}{l}9.57^{\mathrm{b}}(p<0.000) \\
{\left[0.45^{\mathrm{c}}\right]}\end{array}$ \\
\hline Economic damage incurred due to hazards by household/year (USD) & $\begin{array}{l}151.06 \\
( \pm 22.92)\end{array}$ & $\begin{array}{l}137.76 \\
( \pm 15.88)\end{array}$ & $\begin{array}{l}6.39^{\mathrm{b}}(p<0.000) \\
{\left[0.32^{\mathrm{c}}\right]}\end{array}$ \\
\hline Killed/injured (number) & 0.92 & 0.66 & $\begin{array}{l}3.52^{\mathrm{b}}(p<0.000) \\
{\left[0.18^{\mathrm{c}}\right]}\end{array}$ \\
\hline Participation in disaster preparedness training since November $2007(\%)$ & 34.44 & 83.89 & $\begin{array}{l}91.07^{\mathrm{d}}(p<0.000) \\
{\left[0.50^{\mathrm{c}}\right]}\end{array}$ \\
\hline
\end{tabular}

\footnotetext{
${ }^{a}$ Standard deviation in parenthesis (where applicable)

${ }^{\mathrm{b}} \mathrm{z}$ statistics for mean difference test

c Point-Biserial (r) where $0.2,0.5$, and 0.8 refer to small but not trivial, medium, and high effect size, respectively

d Chi-squared statistics
} 
settlement type, poorer access to basic household utilities, and higher proportion of economic damages incurred by hazards. The average land ownership in the upstream and downstream regions was $56.43( \pm 122.01)$ and 18.49 $( \pm 66.64)$ decimals $^{5}$ respectively. The subsequent standard deviation provides a scenario of severe inequality of land ownership pattern, which is interestingly higher in the upstream region. Such land ownership pattern, as reported by the FGD discussants, was triggered by a higher rate of ownership transfer to local landlords by the poor and marginalized households in order to cope with income shock in post-Aila period. Such transfer had eventually made the land ownership very asymmetric in the study area. The population density in the downstream region, especially in Uttar Bedkashi and Dakshin Bedkashi, seemed to be somewhat lower than in the upstream region. Plausible reasons mentioned by the focus group discussion participants were high migration post Aila, long-term inundation, and limited income prospects.

\subsection{Hazard Events and Damage}

In this study, climatic hazards were considered in accordance with the definitional paradigm suggested by the IPCC (2012c). More than 97\% of the respondent households reported being exposed to different climatic hazards throughout the year. Table 3 shows that more than threequarters of the sampled households (both in the downstream region and in the upstream region) reported that cyclones with storm surges and floods had become more frequent in the two decades prior to 2009. Increase in rainfall and temperature anomalies were mentioned by about $59 \%$ of the households, increase in soil salinity intrusion by around $51 \%$, increase in average duration of water-logging by about $52 \%$, increase in riverbank erosion by around $45 \%$, and irregularity in seasonal variation by around $51 \%$. A substantial number of households recounted many times the deadly cyclones and their associated consequences in the form of storm surges, flash floods, and water-logging due to embankment breaches over the two decades prior to 2009, on many occasions in their own and adjacent areas. These hazards caused significant damage to the socioeconomic infrastructure and eventually prompted the coastal people at risk to change their livelihood strategies, consistent with findings in areas adjacent to Koyra (Ahsan 2010, 2014; Saha 2014; Ahsan et al. 2017; Islam et al. 2017). In contrast, soil salinity intrusion is a relatively recent hazard that is likely the consequence of post-cyclone flash floods and long-term water-logging in the study area.

\footnotetext{
5 Decimal is a unit of area in Bangladesh, which is approximately $1 / 100$ acre.
}

The perceived effects and impacts from most of the hazards addressed in this study were found to differ significantly between the upstream and downstream regions of Koyra. The inhabitants of the downstream region suffered more significantly and systematically from climatic hazards such as tropical cyclones and storm surges, soil salinity intrusion, long-term water-logging, riverbank erosion, and irregular season duration (Table 3). No significant and systematic difference was found in terms of the perception of increase in both rainfall and flash floods in the two regions, implying that both regions have experienced a similar trend in the stated hazards. However, upstream households reported experiencing temperature increases more significantly than their counterpart region in the two decades prior to 2009. The observations of focus group discussion participants as well as household respondents emphasized that the downstream region tended to be substantially inundated for a longer time than the upstream region, mainly because of breached embankments in River Sakbaria on the southeastern side and River Kobadak on the southwestern side of downstream Koyra after Cyclone Aila. In addition, the elevation of the land slope in the downstream region is lower than that of the upstream region, and the downstream region usually experienced longer inundation than the upstream region after any moderate or strong tropical cyclone.

The average yearly economic damage to each household due to hazards was calculated as USD $144( \pm 20.79)$ in Koyra, including market values of household assets (for example, fishing boats and livestock) lost due to different hazards. This figure equals about $22 \%$ of a household's yearly total consumption expenditure [USD 654.36 $( \pm 456.45)]$ on average. Households' median economic damage due to hazards was USD 141, more than one-fourth of its yearly total consumption expenditure. Dividing the amount of damage by the median value of a household's yearly total consumption expenditure, the proportion of damage to household yearly consumption expenditure was $26 \%$. The maximum and minimum values of hazard-related economic damage were calculated as USD 210 and USD 110 , respectively, for the sampled households. For the upstream region's households, the disaster damage equaled to nearly $16 \%$ of yearly total consumption expenditure; while in the downstream region it was $35 \%$ of the yearly total consumption expenditure. Therefore, downstream households seemed to be far worse off and much more affected by hazards.

Table 2 shows that the downstream households significantly and systematically incurred more hazard-related economic damage and suffered more structural damage (of houses) than those in the upstream region. Land ownership was affected by both riverbank erosion and inundation duration as reported by the respondents. This situation was 
Table 3 Different hazards perceived by the sampled households in Koyra, Bangladesh, in $2009(n=360)$

\begin{tabular}{|c|c|c|c|c|c|}
\hline \multirow[t]{3}{*}{ Hazards } & \multicolumn{4}{|l|}{ Region } & \multirow[t]{3}{*}{ Chi-squared value ( $p$ value) } \\
\hline & \multicolumn{2}{|c|}{ Downstream $(n=180)$} & \multicolumn{2}{|c|}{ Upstream $(n=180)$} & \\
\hline & Yes $(\%)$ & No $(\%)$ & Yes $(\%)$ & No $(\%)$ & \\
\hline Increase in cyclones with storm surge frequency & 79.44 & 20.56 & 76.59 & 23.41 & $\begin{array}{l}\chi^{2}(1)^{\mathrm{a}}=6.64(p<0.010) \\
{\left[0.29^{\mathrm{b}}\right]}\end{array}$ \\
\hline Increase in flash flood frequency & 78.42 & 21.58 & 76.22 & 23.78 & $\begin{array}{l}\chi^{2}(1)^{\mathrm{a}}=0.84(p<0.668) \\
{\left[0.14^{\mathrm{b}}\right]}\end{array}$ \\
\hline Change in rainfall pattern & 60.56 & 39.44 & 58.33 & 41.67 & $\begin{array}{l}\chi^{2}(1)^{\mathrm{a}}=0.184(p<0.668) \\
{\left[0.02^{\mathrm{b}}\right]}\end{array}$ \\
\hline Increase in average temperature & 52.78 & 47.22 & 66.11 & 33.89 & $\begin{array}{l}\chi^{2}(1)^{\mathrm{a}}=33.64(p<0.000) \\
{\left[0.13^{\mathrm{b}}\right]}\end{array}$ \\
\hline Increase in soil salinity intrusion & 66.11 & 33.89 & 35.56 & 64.44 & $\begin{array}{l}\chi^{2}(1)^{\mathrm{a}}=33.62(p<0.000) \\
{\left[0.31^{\mathrm{b}}\right]}\end{array}$ \\
\hline Increase in average duration of water-logging & 63.33 & 36.67 & 40.56 & 59.44 & $\begin{array}{l}\chi^{2}(1)^{\mathrm{a}}=18.71(p<0.000) \\
{\left[0.28^{\mathrm{b}}\right]}\end{array}$ \\
\hline Increase in riverbank erosion & 50.12 & 49.88 & 39.66 & 60.34 & $\begin{array}{l}\chi^{2}(1)^{\mathrm{a}}=59.88(p<0.000) \\
{\left[0.40^{\mathrm{b}}\right]}\end{array}$ \\
\hline Irregularity in season duration & 36.11 & 63.89 & 66.67 & 33.33 & $\begin{array}{l}\chi^{2}(1)^{\mathrm{a}}=31.78(p<0.000) \\
{\left[0.31^{\mathrm{b}}\right]}\end{array}$ \\
\hline
\end{tabular}

${ }^{\mathrm{a}}$ Degrees of freedom in parenthesis

${ }^{\mathrm{b}}$ Point-Biserial (r) where $0.2,0.5$, and 0.8 refer to small but not trivial, medium, and high effect size, respectively

more acute in the downstream region, where households lost their land due to erosion, and the longer inundation increased the soil salinity of the land. The increased salinity eventually made the land barren and small landholders had to sell their land, increasing the disparity in land ownership in this region, which is consistent with findings by Ahsan and Warner (2014).

\subsection{Coping Mechanism}

A total of 24 practices, as presented in Table 4, were identified in the focus group discussions as coping strategies of the coastal at-risk households in Koyra. They are classified into three categories: practices related to (a) water management, (b) agricultural adjustment, and (c) nonagricultural diversification.

The analysis of the relative frequency of these coping practices indicates that most practices in the three categories differ significantly and systematically between the upstream and downstream regions (Table 4). The two exceptions are the sale of poultry and the renting of land for shrimp farming, which are of similar significance in both regions.

Practices in the water management category significantly differ between the upstream and downstream regions $(z=11.72 ; p<0.000$; effect size: 0.53$)$; such practices are carried out more often in the upstream region. This can be explained by differences in surface topography (for example, elevation of land) and inundation frequency and duration-inundation is more frequent and lasts longer in the downstream region than in the upstream region. Thus, households in the upstream region are able to implement suitable coping practices of water management to meet their needs.

In the case of agricultural adjustment, downstream households carry out one-third more of the total coping practices than upstream households, and the overall practices differ significantly between the regions $(z=12.36$; $p<0.000$; effect size: 0.55 ). This is due to the contrast in the adoption of crop-related farming and aquaculture practices - crop farming is practiced widely by upstream households and aquaculture is dominated by downstream households. This difference in the adoption of practices is likely to depend on the degree and duration of inundation as reported by the respondents.

Nonagricultural diversification is practiced more in downstream households. Because a substantial part of the downstream region was inundated for a period of at least 7 months after Cyclone Aila, nonagricultural activities were the most common coping practices for the purpose of livelihood diversification, including resource collection from the adjacent mangrove forest, the Sundarbans, as 
Table 4 Frequency (\%) of different coping practices in Koyra, Bangladesh, in $2009(n=360)$

\begin{tabular}{|c|c|c|c|}
\hline Coping practices & Downstream $(n=180)$ & Upstream $(n=180)$ & $\begin{array}{l}\text { Test statistic ( } p \text { value) } \\
\text { (effect size) }\end{array}$ \\
\hline \multicolumn{4}{|l|}{ Water management } \\
\hline Construction of reservoir in household for ex situ rain water harvest & 46.67 & 59.44 & $\begin{array}{l}5.89^{\mathrm{c}}(p<0.015) \\
{\left[0.13^{\mathrm{d}}\right]}\end{array}$ \\
\hline Groundwater collection for household use and agricultural production & 35.0 & 55.56 & $\begin{array}{l}15.35^{\mathrm{c}}(p<0.001) \\
{\left[0.21^{\mathrm{d}}\right]}\end{array}$ \\
\hline Surface water collection for agricultural production & 28.89 & 56.11 & $\begin{array}{l}27.29^{\mathrm{a}}(p<0.000) \\
{\left[0.28^{\mathrm{d}}\right]}\end{array}$ \\
\hline Irrigation from canal/river for agricultural production & 25.0 & 48.89 & $\begin{array}{l}22.05^{\mathrm{c}}(p<0.000) \\
{\left[0.25^{\mathrm{d}}\right]}\end{array}$ \\
\hline \multicolumn{4}{|l|}{ Agricultural adjustment } \\
\hline Homestead forestry & 28.33 & 50.56 & $\begin{array}{l}18.61^{\mathrm{c}}(p<0.000) \\
{\left[0.23^{\mathrm{d}}\right]}\end{array}$ \\
\hline Use of organic fertilizer & 6.11 & 39.44 & $\begin{array}{l}56.85^{\mathrm{c}}(p<0.000) \\
{\left[0.40^{\mathrm{d}}\right]}\end{array}$ \\
\hline Use of inorganic fertilizer & 5.01 & 46.67 & $\begin{array}{l}81.55^{\mathrm{c}}(p<0.000) \\
{\left[0.48^{\mathrm{d}}\right]}\end{array}$ \\
\hline Rotation of crops & 19.44 & 58.11 & $\begin{array}{l}54.02^{\mathrm{c}}(p<0.000) \\
{\left[0.45^{\mathrm{d}}\right]}\end{array}$ \\
\hline Flood resistant paddy & 27.78 & 61.67 & $\begin{array}{l}41.81^{\mathrm{c}}(p<0.000) \\
{\left[0.34^{\mathrm{d}}\right]}\end{array}$ \\
\hline Production of vegetables in off-season & 17.80 & 61.11 & $\begin{array}{l}40.5^{\mathrm{c}}(p<0.000) \\
{\left[0.34^{\mathrm{d}}\right]}\end{array}$ \\
\hline Sale of cattle & 16.11 & 67.22 & $\begin{array}{l}69.97^{\mathrm{c}}(p<0.000) \\
{\left[0.44^{\mathrm{d}}\right]}\end{array}$ \\
\hline Sale of poultry & 66.11 & 60.56 & $\begin{array}{l}1.20^{\mathrm{c}}(p<0.274) \\
{\left[0.06^{\mathrm{d}}\right]}\end{array}$ \\
\hline Mixed vegetable production & 18.33 & 61.67 & $\begin{array}{l}70.41^{\mathrm{c}}(p<0.000) \\
{\left[0.44^{\mathrm{d}}\right]}\end{array}$ \\
\hline Floating vegetable garden & 58.89 & 21.67 & $\begin{array}{l}51.84^{\mathrm{c}}(p<0.000) \\
{\left[0.40^{\mathrm{d}}\right]}\end{array}$ \\
\hline Seasonal fishing & 42.22 & 28.33 & $\begin{array}{l}7.60^{\mathrm{c}}(p<0.006) \\
{\left[0.15^{\mathrm{d}}\right]}\end{array}$ \\
\hline Sharecropping & 36.11 & 65.56 & $\begin{array}{l}31.22^{\mathrm{c}}(p<0.000) \\
{\left[0.29^{\mathrm{d}}\right]}\end{array}$ \\
\hline \multicolumn{4}{|l|}{ Nonagricultural diversification } \\
\hline Cottage industry (pottery, bamboo and cane goods, and cool mat) & 30.56 & 51.11 & $\begin{array}{l}15.74^{\mathrm{c}}(p<0.000) \\
{\left[0.21^{\mathrm{d}}\right]}\end{array}$ \\
\hline Daily labor ${ }^{\mathrm{a}}$ & 62.78 & 47.78 & $\begin{array}{l}8.19^{\mathrm{c}}(p<0.004) \\
{\left[0.15^{\mathrm{d}}\right]}\end{array}$ \\
\hline Off-farm contract work ${ }^{\mathrm{a}}$ & 70.56 & 38.33 & $\begin{array}{l}37.67^{\mathrm{c}}(p<0.000) \\
{\left[0.32^{\mathrm{d}}\right]}\end{array}$ \\
\hline Seasonal business & 29.44 & 38.89 & $\begin{array}{l}3.56^{\mathrm{c}}(p<0.059) \\
{\left[0.10^{\mathrm{d}}\right]}\end{array}$ \\
\hline Forest resource collection & 56.22 & 27.22 & $\begin{array}{l}6.83^{\mathrm{c}}(p<0.010) \\
{\left[0.14^{\mathrm{d}}\right]}\end{array}$ \\
\hline Broker $^{\mathrm{b}}$ & 54.44 & 23.33 & $\begin{array}{l}36.65^{\mathrm{c}}(p<0.000) \\
{\left[0.32^{\mathrm{d}}\right]}\end{array}$ \\
\hline
\end{tabular}


Table 4 continued

\begin{tabular}{|c|c|c|c|}
\hline Coping practices & Downstream $(n=180)$ & Upstream $(n=180)$ & $\begin{array}{l}\text { Test statistic } \\
(p \text { value })(\text { effect size })\end{array}$ \\
\hline Renting land for shrimp farming & 37.22 & 36.11 & $\begin{array}{l}1.25^{\mathrm{c}}(p<0.660) \\
{\left[0.05^{\mathrm{d}}\right]}\end{array}$ \\
\hline Temporary migration & 58.89 & 26.67 & $\begin{array}{l}38.17^{\mathrm{c}}(p<0.000) \\
{\left[0.33^{\mathrm{d}}\right]}\end{array}$ \\
\hline \multicolumn{4}{|c|}{$\begin{array}{l}\text { a Daily labor is paid on a daily basis while contract work is paid once the designated job (for example erecting haystacks in a particular place) is } \\
\text { completed irrespective of the required number of days }\end{array}$} \\
\hline
\end{tabular}

mentioned by the survey respondents. Nonagricultural diversification also differed significantly between the upstream and downstream regions $(z=2.83 ; p<0.005$; effect size: 0.15$)$.

In both regions, the number of coping practices related to water management and agricultural adjustment shows a significant inverse correlation with the hazard-related economic damage incurred by the households at risk $\left(r_{\mathrm{w} .-}\right.$ mang $\left.=-0.66, \quad p<0.000 ; \quad r_{\text {agri }}=-0.71, \quad p<0.000\right)$. However, this correlation, although not very strong, is found positive and significant with nonagricultural diversification $\left(r_{\text {n.agri }}=0.18, p<0.000\right)$. The asymmetric pattern (with a skewness of 0.56 ) of the nonagricultural coping practices data may be responsible for this correlation. Nonetheless, there exists a significant inverse correlation between the number of coping practices and hazard-related economic damage in the entire Koyra area $(r=-0.59$, $p<0.000)$.

\subsection{Regression Results}

Table 5 presents the regression coefficients of the explanatory variables of Eq. (1). Columns 2 and 3 present results for the downstream and upstream regions, and column 4 shows the results for the Koyra area as a whole. The tests confirmed that none of the models (columns 2-4) encountered the problem of multicolinearity ${ }^{6}$ and heteroscadisticity. ${ }^{7}$ The adjusted R-squared values in Table 5 explain $71.4,74.7$, and $78.7 \%$ of the total variation (that is, goodness of fit) in the number of adopted coping practices by the explanatory variables presented in columns 2, 3, and 4, respectively, and all three values are

\footnotetext{
${ }^{6}$ The Variance Inflation Factor (VIF) for multicolinearity for columns 2,3 , and 4 are $1.25,1.49$, and 1.4 , respectively.

7 The Breusch-Pagan test for heteroscedasticity for columns 2, 3, and 4 provides value as $\chi^{2}=3.14(p<0.076), \chi^{2}=0.30(p<0.585)$, and $\chi^{2}=2.59(p<0.108)$, respectively.
}

satisfactory enough. Nonetheless, the unexplained variations indicate that a number of predictors (explanatory variables) for explaining coping practices are excluded from the model expressed through Eq. (1), although it is difficult to avoid a phenomenon like this in the process of studying a multifactorial societal system, such as the households' adoption of coping practices in response to climate hazard risks. Not all determinants that might influence household behavior can be measured, given the difference in the aspects and contexts of respondents and their limited degree of willingness to participate in interviews for more than $20 \mathrm{~min}$.

The regression coefficients postulate that except for several explanatory variables, the corresponding signs of the coefficients are in line with the expected signs (that is, relationship with coping practices) presented in Table 1. Household size, dependency ratio, per capita consumption expenditure for basic needs, and the perception of weather indicators were found significantly related with the number of coping practices with the expected signs for the downstream and upstream regions and for the entire Koyra area, as shown in Table 5. Literacy level and information source were found significant, but signs different than expected were found only for the downstream region and Koyra as a whole. For the upstream region, the coefficients of literacy level, information source, and disaster preparedness training participation obtained the expected signs; however, none of these was significant. The expected relationship between the female-male ratio and coping practices was found to be significant only for the upstream region. We found an inverse significant relationship for this region in terms of gender, indicating that male-headed households are unlikely to adopt a higher number of coping practices. We also found the corresponding coefficients of social capital and resource-index value for the downstream region, which were not significant and consistent with the expected signs. 
Table 5 Regression results of variation explained in coping practices of households by different predictors

\begin{tabular}{|c|c|c|c|}
\hline Variables & $\begin{array}{l}\text { Coping practices } \\
\text { downstream }\end{array}$ & $\begin{array}{l}\text { Coping practices } \\
\text { upstream }\end{array}$ & Coping practices in Koyra (both regions) \\
\hline Household size & $\begin{array}{l}0.245 * * * \\
(0.0803)\end{array}$ & $\begin{array}{l}0.115^{*} \\
(0.0659)\end{array}$ & $\begin{array}{l}0.185 * * * \\
(0.0532)\end{array}$ \\
\hline Gender & $\begin{array}{l}0.129 \\
(0.274)\end{array}$ & $\begin{array}{l}-0.648^{*} \\
(0.350)\end{array}$ & $\begin{array}{l}0.163 \\
(0.222)\end{array}$ \\
\hline Female-male ratio & $\begin{array}{l}-0.0759 \\
(0.172)\end{array}$ & $\begin{array}{l}-0.291 * \\
(0.156)\end{array}$ & $\begin{array}{l}-0.131 \\
(0.120)\end{array}$ \\
\hline Dependency ratio & $\begin{array}{l}-4.188^{* * *} \\
(0.649)\end{array}$ & $\begin{array}{l}-4.795 * * * \\
(0.973)\end{array}$ & $\begin{array}{l}-4.380 * * * \\
(0.544)\end{array}$ \\
\hline Literacy level of household heads & $\begin{array}{l}-0.171 * * * \\
(0.0489)\end{array}$ & $\begin{array}{l}0.00705 \\
(0.0320)\end{array}$ & $\begin{array}{l}-0.0563 * * \\
(0.0266)\end{array}$ \\
\hline Social capital & $\begin{array}{l}-0.00311 \\
(0.00770)\end{array}$ & $\begin{array}{l}0.00826 \\
(0.00805)\end{array}$ & $\begin{array}{l}0.00196 \\
(0.00581)\end{array}$ \\
\hline $\begin{array}{l}\text { Per capita consumption expenditure/ } \\
\text { year }\end{array}$ & $\begin{array}{l}0.553 * * * \\
(0.0154)\end{array}$ & $\begin{array}{l}0.653 * * * \\
(0.0163)\end{array}$ & $\begin{array}{l}0.709 * * * \\
(0.0114)\end{array}$ \\
\hline Perceived weather anomalies & $\begin{array}{l}0.139 * * \\
(0.0752)\end{array}$ & $\begin{array}{l}0.800 * * * \\
(0.031)\end{array}$ & $\begin{array}{l}0.336 * * * \\
(0.0656)\end{array}$ \\
\hline Resource index & $\begin{array}{l}-0.143 \\
(0.706)\end{array}$ & $\begin{array}{l}0.351 \\
(0.645)\end{array}$ & $\begin{array}{l}0.333 \\
(0.502)\end{array}$ \\
\hline Information source & $\begin{array}{l}0.197 * * \\
(0.0855)\end{array}$ & $\begin{array}{l}0.135 \\
(0.103)\end{array}$ & $\begin{array}{l}0.277 * * * \\
(0.0606)\end{array}$ \\
\hline Safety-net membership & $\begin{array}{l}0.120 \\
(0.239)\end{array}$ & $\begin{array}{l}0.0778 \\
(0.241)\end{array}$ & $\begin{array}{l}0.205 \\
(0.176)\end{array}$ \\
\hline Preparedness training participation & $\begin{array}{l}2.298 * * * \\
(0.286)\end{array}$ & $\begin{array}{l}0.472 \\
(0.358)\end{array}$ & $\begin{array}{l}1.909 * * * \\
(0.225)\end{array}$ \\
\hline Constant & $\begin{array}{l}7.575 * * * \\
(0.865)\end{array}$ & $\begin{array}{l}5.526 * * * \\
(1.159)\end{array}$ & $\begin{array}{l}6.040 * * * \\
(0.650)\end{array}$ \\
\hline F-statistics & $\begin{array}{l}34.73(12,167) \\
(p<0.000)\end{array}$ & $\begin{array}{l}41.05(12,167) \\
(p<0.000)\end{array}$ & $\begin{array}{l}106.82(12,347) \\
(p<0.000)\end{array}$ \\
\hline Observations & 180 & 180 & 360 \\
\hline Adjusted R-squared & 0.714 & 0.747 & 0.787 \\
\hline
\end{tabular}

Standard errors in parentheses

$* * * p<0.01 ; * * p<0.05 ; * p<0.1$

\section{Discussion}

In both the upstream and downstream regions of Koyra, people at risk perceived intensified climate hazard risks over the two decades prior to 2009, particularly through increased frequency and intensity of cyclone hazards and their consequences in the form of storm surges, flash floods, and water-logging resulting from inundation (Table 3). This finding of increased perceived climatic hazard risk is consistent with the empirical findings by Paul and Dutt (2010), Mallick and Vogt (2012), and Parvin and Shaw (2013) for south and southwestern coastal Bangladesh.

\subsection{Explaining Coping Strategies with a Linear Regression Model}

A multiple linear regression analysis of predictors, which were selected in synergy with a theoretical framework and collected primary data, was applied to explain the coping strategies of at-risk households. Most of the variables considered for this study were discrete in nature, so we did not choose other methods, such as principal component analysis or factor analysis, rather than the regression method. Since the multicollinearity for each of the equations was not problematic, the adopted multiple regression analysis seemed to be a superior method over any multivariate analysis (for example, factor analysis). 
The regression coefficients suggest that the elements of household size, per capita consumption expenditure, and perceived weather anomalies of the socioeconomic asset profile significantly affected the number of coping practices in the upstream, downstream, and whole Koyra study area. Only in the downstream and the whole Koyra region, did literacy level, information source, and preparedness training also significantly affect at-risk household coping practices.

In a situation with almost similar exposure to hazard risk, variation in socioeconomic asset profiles and livelihood options resulted in the difference in the degree to which coastal households at risk adopted coping practices. For instance, after cyclones the downstream region suffered more significantly from inundation due to storm surges, flash floods, and water-logging resulting from embankment breeches and low elevation of land. This seems to provide households significantly and systematically less room for adopting coping practices of water management $(z=8.34$, $p<0.000$; effect size $=0.40)$ and agricultural adjustment $(z=17.02, p<0.000$; effect size $=0.67)$, compared to households in the upstream region (Table 4). The same households adopted significantly and systematically more coping practices of nonagricultural diversification $(z=7.84, p<0.000$; effect size $=0.38)$. The immediate effects and impacts of different climate hazard risks, especially from cyclones, and their consequences, seemed to encourage the downstream households to choose mostly nonagricultural coping practices, including three coping practices of agricultural adjustment (seasonal fishing, floating gardens, and the sale of poultry). Upstream households seemed to specialize in agricultural coping practices with the main focus on crop production and relevant water management practices (Table 4). More than three-fifths of the sampled households in both regions used the sale of poultry as a common coping practice in the case of any covariant shock (for example, flash floods), while the sale of cattle for the same purpose was found more common only among upstream households.

The socioeconomic asset profile of households in terms of dependency ratio, per capita consumption expenditure, poverty status, land ownership, structural damage of houses, hazard-related economic damage, and disaster preparedness differed significantly between at-risk households in the downstream and upstream regions (Table 2). All these factors are significantly correlated with the number of adopted coping practices $\left(r_{\text {poverty }}=-0.72\right.$, $p<0.015 ; \quad r_{\text {expenditure }}=0.29, \quad p<0.000 ; \quad r_{\text {land }}=0.26$, $p<0.000 ; \quad r_{\text {structural-damage }}=-0.65, \quad p<0.041 ;$ $\left.r_{\text {economic-damage }}=-0.71, p<0.000\right)$. These imply that households who adopted a higher number of coping practices were relatively better-off in terms of socioeconomic asset profile (that is, households possess more elements of an asset profile). This is consistent with the findings by Barrett et al. (2001), Yamin et al. (2005a, b), and Wamsler and Brink (2014). These better-off households were less likely to be socioeconomically vulnerable and also less likely to live below the poverty threshold (Table 2). Consistent with this result, the regression results in Table 5 suggest that the number of coping practices in the downstream and upstream regions and Koyra as a whole were significantly affected by both per capita consumption expenditure and perceived weather anomalies, in line with the expected direction (positive) (Table 1). Household size was found to influence coping practices positively and significantly in the upstream and downstream regions and Koyra as a whole, which can be explained by the significant inverse influence of the dependency ratio of households in the areas. The result on literacy level implies that more literate household heads adopted a significantly lower number of coping practices in the downstream region and in Koyra as a whole (opposite to the expected direction) (Table 1); however, this was found opposite for the upstream region. Plausible reasons for this result can be the significant and systematic difference in the literacy level (schooling years) of household heads between the two regions. More specifically, the upstream household heads showed a significantly higher literacy rate (Table 2). In Koyra, the average number of schooling years was found to be 4.45 years, with a high standard deviation of $( \pm)$ 3.12 years. The regression coefficient of the female-male ratio was found significant only for the upstream region with the expected sign. The most likely reason for this result is the higher mean value of the ratio in the upstream region as opposed to the downstream region and Koyra as a whole by 0.21 and 0.103 , respectively [Female-male ratio of Koyra is $0.976( \pm 0.685)]$ (Table 2). The subsequent signs in Table 5 for the female-male ratio were also found in line with the expected inverse direction in relation to coping practices for the downstream region and Koyra as a whole; however, none of the coefficient was found significant. The sampled households that participated in disaster preparedness training in the downstream region and Koyra as a whole more often adopted a higher number of coping practices than those that did not participate. No such trend was found for the households in the upstream region though they participated relatively more frequently in preparedness training than their downstream counterparts. The mean coefficient of relation between the number of accessed information source(s) and coping practices was found significantly different than zero with the expected sign only for the downstream region and Koyra as a whole (Table 5). For the upstream households, such a coefficient was not found significantly different than zero although the obtained direction was found as expected (Table 1). This finding exhibits a strong positive correlation between 
training participation and the number of information source(s) accessible by the sampled households for collecting weather-related updates $(r=0.78, p<0.000)$, implying that the sampled households that attended disaster preparedness training after Cyclone Sidr in 2007 appeared to be more in touch with necessary information sources than before the landfall of cyclone Aila. Both of these determinants also had a positive and significant correlation with coping practices $\left(r_{\text {information }}=0.48, \quad p<0.000\right.$; $r_{\text {training }}=0.74, \quad p<0.000 ; \quad r_{\text {info }} \quad$ vs $\quad$ training $=0.54$, $p<0.000$ ). This implies that stakeholder agencies (either government or nongovernment) succeeded to enhance the awareness of people about climate hazard risks and the most suitable countermeasures through coping practices to minimize the hazard impacts on their generic livelihoods. This constitutes institutional support available for the households at risk to cope with climate hazard risks. No significant relation of safety-net membership, social capital, and resource index was found with coping practices, although in some cases the direction was found as expected.

The above discussion suggests that the households' motivation for adopting coping practices is governed primarily by the degree of possession of elements of socioeconomic asset profile as well as the duration of the consequences of cyclone hazards that are substantially governed by the region's biophysical characteristics. This is in line with the findings by Adger and Kelly (1999), Koli (2013), and Siegel (2005). For instance, the longer inundation period in the downstream region after tropical Cyclone Aila led local inhabitants to choose coping practices of, for example, floating gardens and off-farm activities in contrast with the upstream inhabitants to reduce the adverse impacts of climate extremes. Of the three broad categories of coping practices, all the water management-oriented coping strategies are practiced significantly more frequently by the upstream households than the downstream households. In case of agricultural adjustment related practices, all relevant coping strategies (except sale of poultry, floating gardening, and seasonal fishing) are practiced significantly more by the upstream households. The downstream households practiced all relevant nonagricultural diversification strategies (except cottage industry and seasonal business) significantly more than their counterpart households (Table 4). For these categories, the coastal households in Koyra were heavily dependent on the degree of direct and/or indirect access to natural resources, for example, crop farming, aquaculture, and forest resources from the Sundarbans. On the whole, better-off households, with a higher number of elements of the socioeconomic asset profile, were likely to adopt more coping practices $(r=0.68, p<0.000)$ in both regions of Koyra.

\section{Conclusion}

We have explored and assessed the complex interplay between coping practices and socioeconomic asset profiles of coastal households in Bangladesh. We developed a simple analytical model and examined mutual relationships among the core variables in a systematic way by using primary data on coping practices and conventional indicators of socioeconomic assets, which were collected through a household survey in southwestern coastal Bangladesh. Our results show that coastal households have adopted practices of water management, agricultural adjustment, and nonagricultural diversification to cope with perceived escalating risks from climatic extreme events, such as tropical cyclones, consistent with the findings of studies conducted in Sri Lanka (Truelove et al. 2015), Vietnam (Adger and Kelly 1999), and Bangladesh (Parvin and Shaw 2013; Parvin et al. 2014). The degree of adopting such diverse coping practices is mainly governed by the access to or possession of elements of the socioeconomic asset profile of coastal at-risk households (for example, household size, dependency ratio, per capita consumption expenditure, and perceived weather anomalies), along with biophysical characteristics such as the elevation of land in Koyra. These practices seem to be the best possible strategies for households in both regions of Koyra to reduce adverse impacts of different climatic hazards. This phenomenon becomes apparent from the intention of the asset depletion strategy (for example, sale of livestock) that shields households at risk in the short term from drastic consumption expenditure adjustment, however, at the cost of long-term benefits. Similarly, coping practices that escalate at-risk households' dependency on the adjacent Sundarbans mangrove forest may affect social-ecological resilience in the long run considering the continuation of the current trend (Ahsan et al. 2017), which would eventually aggravate the vulnerability of these coastal households, especially poor and marginalized ones. This may in particular hold true for households living in the Uttar Bedkashi and Dakshin Bedkashi union, which usually suffer from substantial inundation in post-cyclone periods and whose coping practices are dependent on the Sundarbans to a greater extent. Therefore, the possible consequences of existing coping practices in some parts of Koyra raise concerns about whether they are socially and ecologically sustainable, given the weakness in institutional arrangements (for example, poorly defined property rights for common resources). Nonetheless, institutional arrangements in the form of disaster preparedness training show that people at risk become aware of essential information sources that enable them to reduce sensitivity towards impacts of climate hazards. Such preparedness 
training seems to enhance households' long-term adaptive capacity and reduce vulnerability by encouraging them to choose optimal short-run coping practices.

In line with the empirical findings of this study on the role of concern stakeholder agencies to make at-risk people aware of disaster risk and comply with disaster preparedness actions, we recommend the introduction of areaspecific modules on necessary coping practices within the curricula of currently practiced disaster preparedness training. Such modules would help people at risk to understand and adopt relevant coping practices in a sustainable way, maintaining the balance between application of ex-ante risk management and ex-post coping strategies, together with technical solutions in the form of policy instruments. The goal is to ensure efficient contingency procedures, share risks, generate income prospects, and create a platform for ensuring coping capacity in the short run that eventually promotes the adaptive capacity of people at risk in the long run.

The findings and policy recommendation in this paper may not be completely new. Nonetheless, this study has added a very important practical example of copingmechanism and asset-portfolio nexus through a real case that encourages local site-specific studies that are badly needed to make local people at risk resilient toward hazard shocks. The practical lessons from this study may also be helpful for coastal areas with similar contexts across the world. The analysis presented in this article, however, is mainly based on linear and causal relationships. Hence, an important question remains- to what extent these relationships accurately reveal nonlinear causal relationships. For example, the expected relationship between coping practices and the literacy level of household heads was not found consistent in regression results. Furthermore, one result suggests that male-headed households were unlikely to adopt a higher number of coping practices, for which the data did not show a conclusive reason. There might be other reasons for such an interesting finding which we could not address within the specified model (i.e., Eq. 1). The results from this study do not suggest whether the adopted coping practices contribute to a reduction in socioeconomic vulnerability of people at risk. Therefore, we suggest a more extended deterministic model with a wide range of core variables to further test the underlying causal relationships and their directions in future studies.

\footnotetext{
Acknowledgements The author would like to thank G.M. Towhidul Islam from the Urban and Rural Planning (URP) Discipline, Khulna University for helping in preparation of the map. In addition, the author is grateful to Bishawjit Mallick for his comments on the very early draft of the manuscript. The author also thanks the anonymous reviewers for their valuable comments and suggestions to improve this article.
}

Open Access This article is distributed under the terms of the Creative Commons Attribution 4.0 International License (http://crea tivecommons.org/licenses/by/4.0/), which permits unrestricted use, distribution, and reproduction in any medium, provided you give appropriate credit to the original author(s) and the source, provide a link to the Creative Commons license, and indicate if changes were made.

\section{References}

Adger, W.N., and P.M. Kelly. 1999. Social vulnerability to climate change and the architecture of entitlements. Mitigation and Adaptation Strategies for Global Change 4(3-4): 253-266.

Ahsan, M.N. 2010. Climate change and socioeconomic vulnerability: Experiences and lessons from south-western coastal Bangladesh. Master's thesis. Wageningen University, Wageningen, the Netherlands.

Ahsan, M.N. 2014. Effects of livelihood strategies on mangroveforest resource: Do the consumption behaviour of households jeopardise the forest resource base? Management of Environmental Quality: An International Journal 25(6): 696-711.

Ahsan, M.N., K. Vink, and K. Takeuchi. 2017. Livelihood strategies and resource dependency nexus in the Sundarbans. In Participatory mangrove management in a changing climate: Perspectives from the Asia-Pacific, ed. R. DasGupta, and R. Shaw, 137-160. Tokyo: Springer Japan.

Ahsan, M.N., and J. Warner. 2014. The socioeconomic vulnerability index: A pragmatic approach for assessing climate change led risks-A case study in the south-western coastal Bangladesh. International Journal of Disaster Risk Reduction 8: 32-49.

Akter, S., R. Brouwer, P.J. Van Beukering, L. French, E. Silver, S. Choudhury, and S.S. Aziz. 2011. Exploring the feasibility of private micro flood insurance provision in Bangladesh. Disasters 35(2): 287-307.

Balgah, R.A., and G. Buchenrieder. 2010. The dynamics of informal responses to covariate shocks. Journal of Natural Resources Policy Research 2(4): 357-370.

Banglapedia. 2006. Koyra Upazila. Asiatic society. http://www. banglapedia.org/httpdocs/HT/K_0291.HTM. Accessed 19 Mar 2015.

Barrett, C.B., T. Reardon, and P. Webb. 2001. Nonfarm income diversification and household livelihood strategies in rural Africa: Concepts, dynamics, and policy implications. Food Policy 26(4): 315-331.

BBS (Bangladesh Bureau of Statistics). 2005. Household Income and Expenditure Survey (HIES) 2005. Dhaka: Ministry of Planning, Government of People's Republic of Bangladesh.

BBS (Bangladesh Bureau of Statistics). 2011. Population and housing census (preliminary results, July 2011). Dhaka: Bangladesh Bureau of Statistics and Ministry of Planning, Government of People's Republic of Bangladesh. http://www.bbs.gov.bd/webt estapplication/userfiles/image/BBS/PHC2011Preliminary\%20Re sult.pdf. Accessed 22 Jan 2015.

BBS (Bangladesh Bureau of Statistics). 2013. District statistics 2011. Dhaka: Statistics and Information Division, Ministry of Planning, Government of People's Republic of Bangladesh. http:// www.bbs.gov.bd/WebTestApplication/userfiles/Image/District Statistics/Khulna.pdf. Accessed 21 Jun 2015.

Below, T.B., K.D. Mutabazi, D. Kirschke, C. Franke, S. Sieber, R. Siebert, and K. Tscherning. 2012. Can farmers' adaptation to climate change be explained by socioeconomic household-level variables? Global Environmental Change 22(1): 223-235.

Chambers, R. 1994. The origins and practice of participatory rural appraisal. World Development 22(7): 953-969. 
Cutter, S.L., L. Barnes, M. Berry, C. Burton, E. Evans, E. Tate, and J. Webb. 2008. A place-based model for understanding community resilience to natural disasters. Global Environmental Change 18(4): 598-606.

Démurger, S., and M. Fournier. 2011. Poverty and firewood consumption: A case study of rural households in northern China. China Economic Review 22(4): 512-523.

Dercon, S. 2002. Income risk, coping strategies and safety nets. World Bank Research Observer 17(2): 141-166.

Eriksen, S.H., K. Brown, and P.M. Kelly. 2005. The dynamics of vulnerability: Locating coping strategies in Kenya and Tanzania. Geographical Journal 171(4): 287-305.

Field, A. 2005. Comparing two means. In Discovering statistics with SPSS, 2nd edn., 296-304. London: Sage.

Forgette, R., and M. Van Boening. 2009. Measuring and modeling community resilience: SERP and DyME. Southeast Region Research Initiative (SERRI). https://www.researchgate.net/profile/ Mark_Van_Boening/publication/228490028_Measuring_and_Mo deling_Community_Resilience_SERP_and_DyME/links/544042f 50cf2be1758cfff12.pdf. Accessed 15 Jul 2015.

Füssel, H.M. 2007. Adaptation planning for climate change: Concepts, assessment approaches, and key lessons. Sustainability Science 2(2): 265-275.

Gallopín, G.C. 2006. Linkages between vulnerability, resilience, and adaptive capacity. Global Environmental Change 16(3): 293-303.

Helgeson, J.F., S. Dietz, and S. Hochrainer-Stigler. 2013. Vulnerability to weather disasters: The choice of coping strategies in rural Uganda. Ecology and Society 18(2): Article 2.

Heltberg, R., P.B. Siegel, and S.L. Jorgensen. 2009. Addressing human vulnerability to climate change: Toward a "no-regrets" approach. Global Environmental Change 19(1): 89-99.

IPCC (Intergovernmental Panel on Climate Change). 2012a. Summary for Policymakers. In Managing the risks of extreme events and disasters to advance climate change adaptation, ed. C.B. Field, V. Barros, T.F. Stocker, D. Qin, D.J. Dokken, K.L. Ebi, M.D. Mastrandrea, K.J. Mach, G.K. Plattner, S.K. Allen, M. Tignor and P.M. Midgley, 3-22. Cambridge and New York: Cambridge University Press.

IPCC (Intergovernmental Panel on Climate Change). 2012b. Glossary of terms. In Managing the risks of extreme events and disasters to advance climate change adaptation, ed. C.B. Field, V. Barros, T.F. Stocker, D. Qin, D.J. Dokken, K.L. Ebi, M.D. Mastrandrea, K.J. Mach, G.-K. Plattner, S.K. Allen, M. Tignor, and P.M. Midgley, 555-564. Cambridge and New York: Cambridge University Press.

IPCC (Intergovernmental Panel on Climate Change). 2012c. Managing the risks of extreme events and disasters to advance climate change adaptation. Cambridge and New York: Cambridge University Press.

IPCC (Intergovernmental Panel on Climate Change). 2014. Coastal systems and low-lying areas. In Climate change 2014: Impacts, adaptation, and vulnerability. Part A: Global and sectoral aspects. Contribution of working group II to the fifth assessment report of the Intergovernmental Panel on Climate Change, ed. C.B. Field, V.R. Barros, D.J. Dokken, K.J. Mach, M.D. Mastrandrea, T.E. Bilir, M. Chatterjee, K.L. Ebi, Y.O. Estrada, R.C. Genova, B. Girma, E.S. Kissel, A.N. Levy, S. MacCracken, P.R. Mastrandrea, and L.L. White, 361-409. Cambridge and New York: Cambridge University Press.

Islam, R., G. Walkerden, and M. Amati. 2017. Households' experience of local government during recovery from cyclones in coastal Bangladesh: Resilience, equity, and corruption. Natural Hazards 85(1): 1-18.

Kartiki, K. 2011. Climate change and migration: A case study from rural Bangladesh. Gender and Development 19(1): 23-38.
Kelly, P.M., and W.N. Adger. 1999. Assessing vulnerability to climate change and facilitating adaptation. Working Paper. Centre for Social and Economic Research on the Global Environment, School of Environmental Sciences, University of East Anglia, UK.

Kelly, P.M., and W.N. Adger. 2000. Theory and practice in assessing vulnerability to climate change and facilitating adaptation. Climatic Change 47(4): 325-352.

Koli, A. 2013. Community forest management addressing social vulnerability of forest communities in Bangladesh. International Forestry Review 15(3): 336-347.

LGED (Local Government Engineering Department). 2010. Subdistrict level shape files. Dhaka: GIS Division, LGED, Government of People's Republic of Bangladesh.

Lo, A.Y. 2013. The role of social norms in climate adaptation: Mediating risk perception and flood insurance purchase. Global Environmental Change 23(5): 1249-1257.

Mallick, B., and J. Vogt. 2012. Cyclone, coastal society and migration: Empirical evidence from Bangladesh. International Development Planning Review 34(3): 217-240.

Mavhura, E., S.B. Manyena, A.E. Collins, and D. Manatsa. 2013. Indigenous knowledge, coping strategies and resilience to floods in Muzarabani, Zimbabwe. International Journal of Disaster Risk Reduction 5: 38-48.

Michel-Kerjan, E., and H. Kunreuther. 2011. Redesigning flood insurance. Science 333 (6041): 408-409.

Moser, C. 2006. Asset-based approaches to poverty reduction in a globalized context: An introduction to asset accumulation policy and summary of workshop findings. Washington, DC: Brookings Institution.

Parvin, G.A., R. Ahsan, H. Ali, and K.F. Shumi. 2014. Incorporating Microfinance Institutions (MFIs) to enhance food security for poor women vulnerable to extreme climate hazards in rural coastal areas in Bangladesh. Risk, Hazards, and Crisis in Public Policy 5(1): 59-76.

Parvin, G.A., and R. Shaw. 2013. Microfinance institutions and a coastal community's disaster risk reduction, response, and recovery process: A case study of Hatiya, Bangladesh. Disasters 37(1): 165-84.

Parvin, G.A., F. Takahashi, and R. Shaw. 2009. Coastal hazards and community-coping methods in Bangladesh. Journal of Coastal Conservation 12(4): 181-193.

Paul, S.K., and J.K. Routray. 2010. Flood proneness and coping strategies: The experiences of two villages in Bangladesh. Disasters 34 (2): 489-508.

Paul, B.K., and S. Dutt. 2010. Hazard warnings and responses to evacuation orders: The case of Bangladesh's cyclone Sidr. Geographical Review 100(3): 336-355.

Paul, S.K., and J.K. Routray. 2011. Household response to cyclone and induced surge in coastal Bangladesh: Coping strategies and explanatory variables. Natural Hazards 57(2): 477-499.

PDO-ICZMP (Project Director Office-Integrated Coastal Zone Management Project). 2003. Delineation of the coastal zone. Dhaka: Project Director Office-Integrated Coastal Zone Management Project, Government of People's Republic of Bangladesh.

Pelling, M. 2011. Adaptation to climate change: From resilience to transformation. London and New York: Routledge.

Saha, C.K. 2014. Dynamics of disaster-induced risk in southwestern coastal Bangladesh: An analysis on tropical Cyclone Aila 2009. Natural Hazards 75(1): 727-754.

Saroar, M.M., and J.K. Routray. 2011. Impacts of climatic disasters in coastal Bangladesh: Why does private adaptive capacity differ? Regional Environmental Change 12(1): 169-190.

Schmidtlein, M.C., R.C. Deutsch, W.W. Piegorsch, and S.L. Cutter. 2008. A sensitivity analysis of the social vulnerability index. Risk Analysis 28(4): 1099-1114. 
Sen, A. 1981. Poverty and famines: An essay on entitlement and deprivation. Oxford: Oxford University Press.

Siegel, P.B. 2005. Using an asset-based approach to identify drivers of sustainable rural growth and poverty reduction in central America: A conceptual framework. The World Bank Policy Research Working Paper 3475. https://ideas.repec.org/p/wbk/ wbrwps/3475.html. Accessed 11 Nov 2015.

Slangen, L.H.G., L.A. Loucks, and A.H.L. Slangen. 2008. Institutional economics and economic organisation theory: An integrated approach. Wageningen: Wageningen Academic Publisher.

Smit, B., I. Burton, R.J.T. Klein, and J. Wandel. 2000. An anatomy of adaptation to climate change and variability. Climatic Change 45(1): 223-251.

Smit, B., and O. Pilifosova. 2003. Adaptation to climate change in the context of sustainable development and equity. https://www. ipcc.ch/ipccreports/tar/wg2/pdf/wg2TARchap18.pdf. Accessed 17 Mar 2017.

Smit, B., and J. Wandel. 2006. Adaptation, adaptive capacity and vulnerability. Global Environmental Change 16(3): 282-292.

Takagi, T., T. Oguchi, M. Zaiki, and J. Matsumoto. 2005. Geomorphological and geological studies for Bangladesh: A review. Chikei/Transactions, Japanese Geomorphological Union 26(4): 405-422 (in Japanese).

Toufique, K.A., and A. Islam. 2014. Assessing risks from climate variability and change for disaster-prone zones in Bangladesh. International Journal of Disaster Risk Reduction 10: 236-249.

Truelove, H.B., A.R. Carrico, and L. Thabrew. 2015. A sociopsychological model for analyzing climate change adaptation: A case study of Sri Lankan paddy farmers. Global Environmental Change 31: 85-97.

United Nations. 2008. Designing household survey samples: Practical guidelines. New York: United Nations Statistical Division.
United Nations/World Bank. 2010. Natural hazards, unnatural disasters: The economics of effective prevention. Washington DC: World Bank.

Vincent, K., T.C.D. Chanika, P. Hamazakaza, A. Joubert, E. Macome, and C. Mutonhodza-Davies. 2013. Farmers' responses to climate variability and change in southern Africa - is it coping or adaptation? Climate and Development 5(3): 194-205.

Wamsler, C., and E. Brink. 2014. Moving beyond short-term coping and adaptation. Environment and Urbanization 26(1): 86-111.

WHO (World Health Organization). 2011. Tuberculosis Prevalence Surveys: A handbook. http://www.who.int/tb/publications/2010/ limebook20110311prepubcopy.pdf. Accessed 29 May 2015.

Wisner, B., P. Blaikie, T. Cannon, and I. Davis. 2004. At risk: Natural hazards, people's vulnerability and disasters, 2nd edn. London and New York: Routledge.

Wisner, B., J.C. Gaillard, and I. Kelman. 2012. Framing disaster: Theories and stories seeking to understand hazards, vulnerability and risk. In The Routledge handbook of hazards and disaster risk reduction, ed. B. Wisner, J.C. Gaillard, and I. Kelman, 18-33. London: Routledge.

Yamin, F., S. Huq, and A. Rahman. 2005a. Developing the linking climate adaptation network: Progress and prospects. IDS Bulletin 36(4): 123-125.

Yamin, F., A. Rahman, and S. Huq. 2005b. Vulnerability, adaptation and climate disasters: A conceptual overview. IDS Bulletin 36(4): $1-14$.

Yohe, G., and R.S.J. Tol. 2002. Indicators for social and economic coping capacity-moving toward a working definition of adaptive capacity. Global Environmental Change 12(1): 25-40.

Zheng, Y., and A. Byg. 2014. Coping with climate change: Households' response strategies to drought and hailstorm in Lijiang, China. Environmental Hazards 13(3): 211-222. 